Doi: HTTPS://DOI.ORG/10.23910/IJEP/2019.6.3.0321

\title{
Faunistic Survey of Insect-Pests Associated with Agaricus bisporus
}

\author{
Anurag Sharma ${ }^{1}$, Anju Sudhakar Khannaㄹ, Rajeev Raina ${ }^{1}$, Renu Kapoor $^{1}$ and Kehar Singh Thakur ${ }^{1}$
}

${ }^{1}$ Dr. Y. S. Parmar University of Horticulture and Forestry, Krishi Vigyan Kendra, Chamba, H.P. (176 314$)$, India

${ }^{2}$ Dept. of Entomology, Dr. Y. S. Parmar University of Horticulture and Forestry, Nauni, Solan, H.P. (173 230), India

\section{Corresponding Author}

Anurag Sharma

e-mail: anuragiias@gmail.com

\author{
Article History \\ Article ID: IJEP0321 \\ Received in 02 ${ }^{\text {nd }}$ August, 2019 \\ Received in revised form $13^{\text {th }}$ August, 2019 \\ Accepted in final form $22^{\text {nd }}$ August, 2019
}

\begin{abstract}
Present research conducted to acquaint with the insect pest fauna of commercially cultivated mushroom Agaricus bisporus revealed the abundance of insects belonging to orders Diptera and Coleoptera. In addition, spring tails and mites were also of common occurrence. Two genera of flies belonging to families Sciaridae and Phoridae registered their presence in these two mushrooms. Of these, the most prevalent grayish black small fly with filiform antennae, typical sciarid wings, long legs with contiguous coxae and elongated abdomen was identified as Sciara sp. (Diptera: Sciaridae). Though, this fly has been recorded from mushrooms from many mushroom growing nations of the world, it has been reported for the first time in Himachal Pradesh. Besides, Megaselia sp. (Diptera: Phoridae) was observed in two locations only. Incidence of four genera of beetles viz., Cyllodes indicus, Scaphisoma nigrofasciatum, Staphylinus sp. and Spondotriplax pallidipes was also recorded.
\end{abstract}

Keywords: Agaricus bisporus, Coleoptera, Diptera

\section{Introduction}

Mushroom production represents one of the most significant indoor commercial enterprises towards diversification of agriculture based on microbial technology for large scale recycling of agro-wastes and their transformation into edible biomass, accepted as highly nutritive food with royal flavor and palatability. The important commercially cultivated mushrooms in the nation are, white button mushroom, Agaricus bisporus (Lange) Imbach (85.0\%), oyster mushroom, Pleurotus spp.(24.1\%).

Most of the cultivation in the country is undertaken by marginal farmers under unhygienic conditions in improvised mushroom farms which prove to be the hot beds for multiplication of various pests and pathogens. Arthropod pests of concern in mushroom cultivation are dipteran flies, coleopteran beetles and spring tails. Most abundant and menacing among them are small to medium size delicate dipteran flies often bearing resemblance to gnats and midges. These flies are exceedingly numerous in individuals and species with a wide geographical range (Brown and Marshal, 1984; Chakarvarty et al., 1987; Brar and Sandhu, 1989; Kumar and Sharma, 2000; White and Smith, 2000). More than 13 genera belonging to six families of these flies have been found to be associated with mushroom cultivation. These are the major pests of mushroom throughout the world with extremely low economic threshold levels. Uncontrolled populations of these pests can result in substantial losses in yield due to both direct feeding by maggots and associated disease spread by adult flies. These factors necessitate the use of management tools even at low larval densities.

Sciarids are small to medium sized delicate flies of smaller to medium size, often bearing resemblance to gnats and midges. In nature, sciarids inhabit leaf mould, wild fungi and rotting vegetable matter. Sciarids are initially attracted to the fermentation odors being emitted during cool down of peak heated compost (Richards and Davies, 1977). Different sciarid genera infesting mushrooms show slight variations in their behavior and biology. Phorid fly Larvae are 4-6 mm long with a white and transparent body and lacked a distinct black head. Larvae fed on mycelia and made cavities in mushroom fruiting bodies. They usually occur during summer cultivation and caused less damage than other flies (Jesse, 2005).

\section{Materials and Methods}

Samples for immature stages of insects were collected from composting ingredients as well as cropping beds in fresh polythene bags, sealed properly with rubber bands to avoid moisture losses and labeled for locality, cropping time and date of collection. Samples brought to laboratory 
were processed for studying the incidence of insects and springtails without undue delay. Precaution was taken to maintain optimum moisture level until the analysis was complete. Adult insects hovering over the cropping bags and inside the mushroom farms were collected by different methods, with or without net only for identification purpose. Dry and wet collections ( $70 \%$ alcohol) of the captured stages were prepared. Yellow traps were laid in the cropping rooms of three farms located in nearby vicinity of Maryog, Jatoli and Nauni University farm for seven days to have an idea of adult insect population in the cropping rooms. 'Pest O Lure' [Pest Control (India) PVT. Ltd.] traps were used to trap the adult flies.

Dipteran insects were collected with the help of yellow traps. Yellow bulb of $15 \mathrm{~W}$ was placed in between two polythene sheets (supported by card board) of $12 \times 15 \mathrm{~cm}^{2}$ size coated with mustard oil among the bags at a height of $60 \mathrm{~cm}$ from the ground. The bulb was switched on from 5 p.m. to 8 a.m. Polythene sheets with insects sticking to them were brought to the laboratory once in a week and the insects were identified and counted separately.

The beetles and their grubs were collected from individual sporocarp and the mean number of beetles or grubs sporocarp $^{-1}$ was calculated. Springtails were extracted with plastic funnel with a piece of rubber tube $(10-12 \mathrm{~cm})$ bearing a glass vial of $5 \mathrm{ml}$ capacity attached to its distal end. The substrate sample with expected fauna was placed over the wire net gently. A table lamp was fixed over the sample enabling prevalent fauna started to move downwards and was collected in the glass vial.

\section{Results and Discussion}

Faunistic incidence of insect pests in $A$. bisporus has been referred in Table 1. The insects belonging to two orders viz.,

Table 1: Insect fauna associated with white button mushroom, Agaricus bisporus in three districts of Himachal Pradesh

\begin{tabular}{|c|c|c|c|c|c|c|c|c|c|c|c|c|c|}
\hline \multirow{3}{*}{$\begin{array}{l}\text { Sr. } \\
\text { No }\end{array}$} & \multirow[t]{3}{*}{ Location } & \multirow{3}{*}{$\begin{array}{c}\text { Sample } \\
\text { descrip- } \\
\text { tion }\end{array}$} & \multicolumn{6}{|c|}{ Diptera } & \multicolumn{5}{|c|}{ Coleoptera } \\
\hline & & & \multicolumn{3}{|c|}{$\begin{array}{c}\text { Sciarids } \\
\text { (Sciara sp.) }\end{array}$} & \multicolumn{3}{|c|}{$\begin{array}{c}\text { Phorids } \\
\text { (Megaselia sp.) }\end{array}$} & \multicolumn{2}{|c|}{$\begin{array}{l}\text { Cyllodes } \\
\text { indicus }\end{array}$} & \multicolumn{2}{|c|}{$\begin{array}{l}\text { Staphylinus } \\
\text { sp. }\end{array}$} & $\begin{array}{c}\text { Scaphisoma } \\
\text { nigrofasciatum }\end{array}$ \\
\hline & & & MS & PPS & Adults & MS & PPS & Adults & Grubs & Adults & Grubs & Adults & Grubs Adults \\
\hline
\end{tabular}

\section{Distt. Shimla}

\begin{tabular}{|c|c|c|c|c|c|c|c|c|c|c|c|c|c|c|}
\hline 1. & Fagu & $\mathrm{CB}$ & 10 & 3 & NA & - & - & - & - & - & 1 & 1 & - & - \\
\hline 2. & & CA & - & - & NA & - & - & - & - & - & - & - & - & - \\
\hline 3. & & $\mathrm{CB}$ & - & - & NA & - & - & - & - & - & - & - & - & - \\
\hline 4. & & $\mathrm{~S}$ & 8 & 3 & NA & - & - & - & - & - & 1 & 1 & - & - \\
\hline 5. & Theog & $\mathrm{CB}$ & 12 & 6 & NA & - & - & - & - & - & 1 & 2 & - & - \\
\hline 6. & & $\mathrm{CB}$ & 17 & 5 & NA & - & - & - & - & - & 1 & 1 & - & - \\
\hline 7. & & CA & 6 & 3 & NA & - & - & - & - & - & - & - & - & - \\
\hline 8. & & $\mathrm{~S}$ & 9 & 4 & NA & - & - & - & - & - & 2 & 2 & 1 & 2 \\
\hline 9. & Shimla & $\mathrm{CB}$ & 12 & 4 & NA & - & - & - & - & - & - & - & - & - \\
\hline 10. & & CA & 5 & 1 & NA & - & - & - & - & - & - & - & - & - \\
\hline 11. & & $\mathrm{~S}$ & 18 & 2 & NA & - & - & - & - & - & - & - & - & - \\
\hline \multicolumn{15}{|c|}{ Distt. Sirmaur } \\
\hline 1. & Maryog & $\mathrm{CB}$ & 27 & 12 & NA & - & - & - & 5 & 3 & - & - & - & - \\
\hline 2. & & $\mathrm{CA}$ & 10 & 6 & NA & - & - & - & - & 1 & - & - & - & - \\
\hline 3. & & $\mathrm{CB}$ & 12 & 4 & NA & - & - & - & 1 & 2 & - & - & - & - \\
\hline 4. & & $\mathrm{CB}$ & 28 & 2 & 417 & - & - & - & - & - & - & - & - & - \\
\hline 5. & & $\mathrm{~S}$ & 19 & - & 2 & - & - & - & 3 & 4 & - & - & - & - \\
\hline 6. & Dumki & $\mathrm{CA}$ & - & - & NA & - & - & - & - & 1 & 2 & 1 & - & - \\
\hline 7. & & $\mathrm{CB}$ & 5 & 2 & NA & - & - & - & - & - & - & - & - & - \\
\hline 8. & & $\mathrm{CB}$ & 8 & 6 & NA & - & - & - & 1 & 2 & 1 & 1 & - & \\
\hline 9. & Paonta sahib & $\mathrm{CB}$ & - & - & NA & - & - & - & - & - & - & - & - & - \\
\hline
\end{tabular}

Table 1: Continue... 


\begin{tabular}{|c|c|c|c|c|c|c|c|c|c|c|c|c|c|c|}
\hline \multirow{3}{*}{$\begin{array}{l}\text { Sr. } \\
\text { No }\end{array}$} & \multirow[t]{3}{*}{ Location } & \multirow{3}{*}{$\begin{array}{l}\text { Sample } \\
\text { descrip- } \\
\text { tion }\end{array}$} & \multicolumn{6}{|c|}{ Diptera } & \multicolumn{6}{|c|}{ Coleoptera } \\
\hline & & & \multicolumn{3}{|c|}{$\begin{array}{c}\text { Sciarids } \\
\text { (Sciara sp.) }\end{array}$} & \multicolumn{3}{|c|}{$\begin{array}{c}\text { Phorids } \\
\text { (Megaselia sp.) }\end{array}$} & \multicolumn{2}{|c|}{$\begin{array}{l}\text { Cyllodes } \\
\text { indicus }\end{array}$} & \multicolumn{2}{|c|}{$\begin{array}{l}\text { Staphylinus } \\
\text { sp. }\end{array}$} & \multicolumn{2}{|c|}{$\begin{array}{c}\text { Scaphisoma } \\
\text { nigrofasciatum }\end{array}$} \\
\hline & & & MS & PPS & Adults & MS & PPS & Adults & Grubs & Adults & Grubs & Adults & Grubs & Adults \\
\hline \multicolumn{15}{|c|}{ Distt. Solan } \\
\hline 1. & Nauni & $\mathrm{CB}$ & 25 & 9 & 516 & 13 & 5 & 5 & - & - & 1 & 1 & - & - \\
\hline 2. & & CA & 8 & 2 & - & 10 & 7 & 3 & - & - & - & - & - & - \\
\hline 3. & & $\mathrm{CB}$ & 12 & - & NA & 5 & 1 & 4 & - & - & - & - & - & - \\
\hline 4. & & $\mathrm{CB}$ & 6 & - & - & 9 & 5 & 4 & - & - & - & - & - & - \\
\hline 5. & & $S$ & - & - & - & - & - & - & - & - & - & 1 & 1 & 1 \\
\hline 6. & Shamlech & CA & 5 & 2 & NA & - & - & - & - & - & - & - & - & - \\
\hline 7. & & $\mathrm{CB}$ & 15 & 7 & NA & - & - & - & - & - & 2 & 1 & - & - \\
\hline 8. & & S & 8 & 2 & NA & - & - & - & - & - & 1 & 1 & - & - \\
\hline 9. & Jatoli & $\mathrm{CB}$ & 32 & 15 & 810 & - & - & - & - & - & - & - & 3 & 4 \\
\hline 10. & & CA & 12 & 5 & - & - & - & - & - & - & - & - & - & - \\
\hline 11. & & $\mathrm{CB}$ & 19 & 11 & NA & - & - & - & - & - & - & - & 7 & 2 \\
\hline 12. & & $S$ & 26 & - & 4 & - & - & - & - & - & - & - & - & - \\
\hline
\end{tabular}

MS: Maggots $250 \mathrm{cc}^{-1}$ sample; PPS: Pre-pupae or Pupae $250 \mathrm{cc}^{-1}$ sample; CB: Cropping Bag; CA: Casing Soil; S: Spawned bags; PS: Platform soil; NA- Not present

Diptera and Coleoptera were significant by their presence or abundance in the mushroom units cultivating white button mushrooms. Order Diptera was represented by the flies belonging to two families viz., Sciaridae and Phoridae. Three genera of beetles belonging to different families of Order Coleoptera were noticed in the cropping bags or rooms. Among Dipterans, Sciarid flies were found to be most widely distributed as they prevailed in most of the samples collected from 9 locations of three mushroom growing districts viz., Shimla, Sirmaur, Solan were covered during the survey. No pest infestation was observed in the purposely built commercial farm of Paonta Sahib (District Sirmaur) due to proper hygiene and scientific methods of cultivation adopted there. The flies belonging to genus Sciara sp. were found to be prevalent in the cropping beds. These flies were attracted to the aroma of compost and were captured in large numbers on yellow traps laid to monitor the adult population in the units located at Jatoli and Nauni (Distt. Solan) and Maryog (Distt. Sirmaur). While most of the adults hovered over the cropping bags, their maggots were mainly found in compost as well as casing medium. Larval forms were also spotted in large numbers inside the sporophores when they were cut open. Larval population of sciarids ranged between 3-85 sciarids $250 \mathrm{cc}^{-1}$ sample in different units depending upon the prophylactic measures adopted against these flies by the growers. Lowest count of three individuals of Sciara sp. was recorded in Kathiyala (Distt. Kullu) and the highest population of 85.0 were recorded in Sehal (Distt. Kangra). Prevalence of these flies in such high numbers in most of the farms was much above the threshold level of one adult. Interestingly, phorids were observed to be of rare occurrence and were encountered in small numbers in three units only, out of total 23 surveyed. Their count varied from 5-29 insects 250 $\mathrm{cc}^{-1}$ sample; minimum restricted to five in Nauni (Distt. Solan) and maximum of 29 counted in University Farm, Kangra. All the phorids collected during these studies were identified as Megaselia sp.

Insects, nematodes, mites and springtails constitute the important groups of mushroom pests. Of these, insects belonging to orders viz., Diptera and Coleoptera are of paramount significance. Order Diptera is represented by the flies belonging to six families viz., Sciaridae, Phoridae, Cecidomyiidae, Scatopsidae, Drosophilidae and Sphaeroceridae (Lewandowski et al., 1999; Navarro et al., 2000, Smith and Gupta, 2002; Deepthi et al., 2003; Greenslade and Clift, 2004 and Jesse, 2005). A few genera of beetles belonging to different families of Coleoptera frequently prevail in the cropping beds (Johal et al., 1992; Lewandowski et al., 1999; Deepthi et al., 2004; Kumar, 2006; Mazumdar et al., 2008). These pests incur pronounced qualitative as well as quantitative losses to mushrooms all over the world (Deepthi et al., 2003; Clift and Terras, 2000; Kumar and Sharma, 2000). The investigations carried out till date are scattered in nature and are confined mainly to Agaricus bisporus.

\section{Conclusion}

Sciara sp. recorded for the first time from mushrooms in the country was very prevalent as it infested both the mushrooms under reference in distantly located farms of various districts 
under survey, working under unhygienic make shift rooms. In most of the locations, the fly count was above the threshold level. With such a high incidence and practically no previous information regarding the status of this insect in mushroom cultivation under Indian conditions available.

\section{References}

Brar, D.S., Sandhu, G.S., 1989. Biology of sciarid fly, Bradysia tritici (Coq.) (Diptera: Sciaridae) on temperate button mushroom in Punjab (India). Mushroom Science 12, 831-842.

Brown, B.V., Marshal, S.A., 1984. Proceeding of Entomological society of Ontario $115,77-80$.

Chakravarty, D.K., Sarkar, B.B., Datta, S., Chatterjee, M.L., 1987. Bionomics and control of sciarid fly, Lycoriella mali Winn. in subtropical mushroom Pleurotus sajor-caju (Fr.) Sing. Indian Mushroom Science 11, 146-150.

Clift, A.D., Terras, M.A., 2000. How many pests can a farm tolerate? AMGA J, 6-7.

Deepthi, S., Suharban, M., Geetha, D., Prathapan, K.D., 2003. Record of new pests of oyster mushrooms in Kerala. Mushroom Research 12, 127.

Deepthi, S., Suharban, M., Geetha, D., Sudharma, K., 2004. Pests infesting oyster mushrooms in Kerala and the seasonality of their occurrence. Mushroom Research 13, 76-81.

Greenslade, P., Clift, A., 2004. Review of pest arthropods recorded from commercial mushroom farms in Australia. Australian Mycologist 23, 77-93.

Jesse, J., 2005. Pest and disease management: pest. In: Mushroom Growers' Handbook. MushWorld.com. pp. 180-182.

Johal, K.K., Kaushal, S.C., Mann, J.S., 1992. A new species of Cyllodes (Coleoptera:Cucujoidea:Nitidulidae) infesting Pleurotus sajor caju in India. Mushroom Research 1, 95-98.
Kielbasa, R., Snetsinger, R., 1981. Life history of the sciarid fly Lycoriella mali and its injury threshold on the common mushroom. Bulletin of the Pennsylvania College of Agriculture 833, 11.

Kumar, S., Sharma, S.R., 2000. Phorids affecting mushroom production and their management-a review. Mushroom Research 9, 55-69.

Kumar, S., 2006. Faunistic studies on cultivated edible mushrooms and biomanagement of their nematode pests. Ph. D Thesis, UHF, Nauni, Solan, 157.

Lewandowski, M., Dmowska, E., Ignatowicz, S., 1999. Fauna of the oyster mushroom houses. Progress in Plant Protection 39, 463-466.

Mazumder, N., Dutta, S.K., Gogoi, R., Rathaiah, Y., 2008. Seasonal abundance of Scaphisoma tetrastictum Champ on oyster mushroom and its relation to meteorological factors. Acta Phytopathologica-et-Entomologica Hungarica 43, 55-62.

Navarro, M.J., Escudero, A., Gea, F.J., Lopez, L.A., Garcia, M.J.A., Ferragut, F., 2000. Determination and seasonal abundance of dipterans in mushroom crops in Castilla La Mancha (Spain). Boletinde Sanidad Vegetal, Plagas 26, 527-536.

Richards, P., Davies, R.G., 1977. Imm's General Text Book of Entomology 10th edition. Vol. II, Chapman and Hall, New York.

Smith, J., Gupta, A., 2002. A new fly pest in mushrooms. Mushroom Journal 627, 6-7.

White, P.F., Smith, J.E., 2000. Bradysia lutaria (Winn.) (Diptera: Sciaridae)- a recent addition to British Fauna and a pest of commercial mushroom farms in Britain. Entomologist's Monthly Magazine 136, 207-209. 